\title{
Being Muslim in a Global Pandemic: Reflections of a Former Niqabi
}

\author{
Baheejah Aaliyah Fareed*
}

On December 31, 2019, Chinese health officials informed the World Health Organization (WHO) about a collection of 41 patients with a peculiar form of pneumonia. Before this phenomenon, it was common to see Chinese traveling worldwide while wearing a face mask. So when the US reported its first case of the novel coronavirus in late January 2020, seeing some American residents wearing a face mask was not an obvious clue as to how profoundly COVID-19 would affect the way we live our daily lives in the "indestructible" and "free" United States of America. Nor was this epoch an indication of how a virus could help people empathize with each other no matter their cultural background or spiritual faith practice.

Considering the current state of the world with our new masked "uniform," it is interesting to see how so many people who had frowned upon the niqab (which some Muslim women choose to wear to prevent spreading "the virus" of female objectification) now feel the need to wear a mask to prevent the spread of a microscopic parasite known as a virus. Many Muslim women also wear it as an expression of freedom. In my case it was a form of feminism, for it forced people to deal with my mind and modesty in lieu of my body and sexuality.

Although I no longer feel the need to wear the niqab to be respected for my mind and morality, I can still empathize with women who choose that way of life. For eleven years I felt it was best to cover my face in public to keep my spirituality alive. To me, losing spirituality in society is akin to death. Such niqabis who are concerned about morality dying in a given society are seen as extremist, oppressed, and hot (from the sun). Consequently, there is a double standard when it comes to face covering, especially in Paris and similar places. Internationally, Paris is promoted as a place of freedom and a defender of a woman's right to be uncovered, but not to be covered. In that city, covering one's face is discouraged if the goal is to maintain a healthy spirit and encouraged only to keep one's body healthy.

About a decade ago I was on a flight from Saudi Arabia to the US and had an eight-hour layover in Paris. Naturally I wanted to see the sights of a place that is

\footnotetext{
* Baheejah Aaliyah Fareed is the Administrative Coordinator, The Islamic Seminary of America, Richardson, TX.
} 
marketed worldwide as the "Mecca" of bucket list destinations, the place where all the "feel goods" are exemplified (food, freedom, art, and fashion). I was confused by the actions of the niqabi women on the plane - they had removed their veils when we landed. I would soon come to learn the influence of discrimination and isolation. When I attempted to leave the airport to explore the city, the airport official told me, "No pass." I stood my ground and demanded that a female attendant "pass" me by viewing my face when I lifted my veil.

This was supposed to be a place for women's rights and liberty, but obviously not for religious freedom. It is still curious to me how France has banned covering the face (for religious freedom), and yet now has face covering requirements, albeit I no longer choose or feel the need to wear a niqab. Previously, the French laughed at and ridiculed niqabi women (some still do), but now many of them are experiencing the emotions associated with the need to cover their faces in public in ways that are very similar to those of Muslim women. Yes it is hot, uncomfortable, not fashion forward; however, its wearing is now necessary to save lives.

While the coronavirus has given many people the chance to empathize with how some Muslims feel, it has undoubtedly challenged our ability to practice our faith. For instance, we see that stopping on the road to use a public restroom to perform ablution and then observe our devotional prayers is presently a thing of the past. Mosques are empty, and the inconceivable -cancelling the hajj season for most of the world's Muslims - has actually happened.

The whole world is indubitably feeling the pain of restrictions being placed on our ways of life. We all have something incontestably in common: living with heightened safety precautions, including covering our faces in public, being obsessed with hand sanitizer/foaming soap, social distancing, and a concern for the future of life as we knew it. As a Muslim woman striving to be seen and respected as a human being, I cannot help but feel gratitude and hope that maybe my Lord is using the novel coronavirus to bring the right people together in order to share a much-needed collaborative effort to advocate on behalf of all humanity. 